INTERNATIONAL HIGHER EDUCATION Number 75 Spring 2014

Pages 10-12

\title{
APEC's Bold Higher Education Agenda: Will Anyone Notice?
}

\author{
CHRISTOPHER ZIGURAS
}

Christopher Ziguras is deputy dean, at the School of Global, Urban and Social Studies, RMIT University, Melbourne, Australia. E-mail: chris.ziguras@rmit.edu.au.

Since the Asia Pacific Economic Cooperation organization (APEC) was established in 1989 to foster economic cooperation across the Asia Pacific it has not been particularly interested in higher education, but that might be changing. During Russia's chairmanship of APEC in 2012, the organization's leaders committing to promoting cross-border cooperation, collaboration, and networking. But whether the organization's new aspiration for regional engagement can be translated into practical measures that affect institutions, students and educators remain to be seen.

\section{A Trade Liberalization Meets Chinese Regulation}

Since at least the mid-1990s, APEC expressed an interest in expanding foreign investment in education and training. Australia, a key provider of cross-border higher education in the region, was the driving force behind early APEC international education projects, while playing a similar role within the World Trade Organization and the Organization for Economic Cooperation and 
Development. In an effort to engage APEC in the Millennium Round of the General Agreement on Trade in Services negotiations, it organized a "Thematic Dialogue on Trade in Education Services" in Hanoi in 2002 and sponsored a series of research projects: Measures Affecting Trade and Investment in Education Services in the Asia-Pacific Region (with New Zealand, 2001), APEC and International Education (2008), and Measures Affecting Cross-Border Exchange and Investment in Higher Education in the APEC Region (2009).

China was much more interested in projects focusing on effective national regulation of cross-border provision. After introducing new guidelines for foreign providers in 2003, China sponsored a project that Australia and New Zealand were keen to partner in, culminating in an awkwardly titled report, Improving the Institute Capacity of Higher Education under Globalization: Joint Schools among APEC (2004). More recently, China held an APEC seminar in Shanghai followed by the report Capacity Building for Policies and Monitoring of Cross-Border Education in the APEC Region (2011).

While coming at the challenge of governing cross-border higher education from opposite poles, both the Australian and Chinese-led projects emphasized the importance of national regulation and quality assurance. In an effort to develop such capacity across the region, Australia and the United States led APEC projects on the development of national quality-assurance regimes in 2006 and 2011, respectively.

These various forums and reports provided some opportunities for information sharing between midranking officials from across the region, which may have contributed in some small part to policy convergence, especially by exposing officials in emerging economies to the practices of more developed 
systems. However, such concerns did not figure large on the agenda of APEC's education ministers. There was rarely even a mention of higher education in the statements of APEC Education Ministerial Meetings before 2012.

\section{What Is Going ON IN Vladivostok?}

In 2012, education ministers agreed to ramp up APEC's role in educational cooperation, dubbed the "Gyeongju Initiative," and immediately the Russian Federation volunteered to lead a higher education initiative during the year in which Russia assumed the rotating leadership of the organization. APEC trade ministers then called for both expanding "cross-border trade in education services and deepening educational cooperation in the Asia-Pacific" (my emphasis). They asked officials to examine ways to "better facilitate mobility of students, researchers and providers in the region." A month later, the Russiansponsored higher education conference in Vladivostok "Shaping Education within APEC" adopted the trade ministers' list and added two more points: "increasing the interaction between higher education institutions and increasing data collection on trade in education services."

In committing to "educational cooperation and promoting cross-border exchange in education services," APEC has wisely framed aspirations in terms that are broad enough to be meaningful within both the education and trade sectors. These aspirations were duly endorsed by APEC Economic Leaders' Meeting in Vladivostok in late 2012. Russia had since sponsored a second APEC Conference on Cooperation in Higher Education in Asia-Pacific Region early in 2013, again in Vladivostok. 
So Russia seems to have very successfully put cross-border higher education on the top of the APEC agenda. Russia does host a large number of international degree students, 129,690 in 2010 according to UNESCO figures; but a small proportion of these are from APEC member economies, with the vast majority coming from former Soviet states. Also, Russia has not previously been active in this space within APEC.

The location may provide some clues. The Leaders' Summit took place on the newly built island campus of the Far Eastern Federal University, which was constructed in time to host the summit and will then provide facilities for the university. The university's Web site states that "The main target of the FEFU Strategic Program for 2010-2019, supported by extensive federal funding, is to make FEFU a world-class university, integrated into the education, research and innovation environment of the Asia-Pacific region." So, the city of Vladivostok and this international university, in particular, appear central to Russia's efforts to expand its educational engagement with the region.

\section{ONGOING Tensions}

In August last year, I facilitated an APEC forum in Kuala Lumpur, Malaysia, sponsored by the Australian Department of Foreign Affairs and Trade that brought together trade and education officials, scholars, and representatives of educational institutions from 14 countries. Much of the discussion focused on ways to enhance institutional capacity, to support a widespread desire for greater international engagement-for recruiting international degree students, engaging in exchange relationships, collaborating with foreign institutions to deliver international programs, internationalizing research, or teaching. 
However, in order to further opening education systems to allow more mobility for students, scholars, and providers, there are still clearly significant differences of opinion between and within countries. Several participants argued that because of the different stages of development of national systems there is not a level playing field; and that introducing greater international competition for domestic providers would undermine their national development strategies.

It is not uncommon for incumbents in any protected industry sector to oppose measures that would allow competitors to enter their markets. In some ways, universities behave no differently than the events of other service providers, such as banks or airlines. But the education sector plays a unique role and is of critical importance in fostering social and economic development. Thus, governments are wary of introducing changes that key institutions see as weakening their positions, especially if those institutions are operated by the ministry of education.

We may not be on the verge of another Bologna Declaration, but APEC's interest is one more indication of a growing political will to intensify the integration of higher education systems across the region. 